\title{
Pengaruh Penambahan Berbagai Jenis Sumber Karbon, Nitrogen Dan Fosforpada Medium deMan, Rogosa and Sharpe (MRS) Terhadap Pertumbuhan Bakteri Asam Laktat Terpilih Yang Diisolasi Dari Intestinum Udang Penaeid
}

\author{
Subagiyo ${ }^{1,2^{*}}$, Sebastian Margino2, dan Triyanto² \\ IJurusan IImu Kelautan, Fakultas Perikanan dan Ilmu Kelautan, Universitas Diponegoro \\ JI. Prof. Soedarto, SH. Kampus UNDIP Tembalang, Semarang 50275 \\ 2Program Studi Bioteknologi Program Pascasarjana Universitas Gadjah Mada \\ Jl. Teknika Utara, Pogung, Sleman, Yogyakarta, 55281 \\ Email :subagiyo_kelautan@yahoo.co.id
}

\begin{abstract}
Abstrak
Bakteri asam laktat merupakan fastidious organisms, tumbuh dengan baik pada medium kompleks. Salah satu medium yang telah diakui baik untuk produksi sel bakteri asam laktat adalah medium deMan, Rogosa and Sharpe (MRS). Pada penelitian ini telah dilakukan penelitian pengaruh penambahan komponen nutrisi pada medium MRS terkait upaya untuk mendapatkan komposisi medium yang lebih baik untuk produksi massa sel. Selain itu juga dilakukan pengamatan pertumbuhan pada berbagai nilai $\mathrm{pH}$ dan suhu. Eksperimen penambahan komponen nutrisi pada medium MRS meliputi sumber karbon (glukosa dan fruktosa) sebanyak $1 \%$, sumber nitrogen (amonium klorida, amonium nitrat, amonium sulfat dan pepton) sebanyak $0,2 \%$, dan sumber fosfor $\left(\mathrm{K}_{2} \mathrm{HPO}_{4}\right.$ danKH $\left.\mathrm{PO}_{4}\right)$ sebanyak $0,1 \%$. Pengamatan pertumbuhan dilakukan dengan metode spektrofotometri berdasarkan perubahan optical density kultur bakteri. Hasil penelitian menunjukan bahwa penambahan glukosa maupun fruktosa memberikan pengaruh menurunkan produksi sel pada awal waktu pertumbuhan (pengamatan 6 jam pertama), tetapi memberikan pengaruh meningkatkan produksi sel setelah waktu pertumbuhan 18 jam dan 24 jam. Perlakuan penambahan sumber nitrogen menunjukan bahwa penambahan pepton memberikan pengaruh meningkatkan produksi sel paling tinggi pada 6 jam kultivasi, selanjutnya mulai 18 jam kultivasi menunjukan penambahan amonium klorida memberikan pengaruh yang paling besar terhadap peningkatan produksi sel. Perlakuan penambahan $\mathrm{K}_{2} \mathrm{HPO}_{4}$ maupun $\mathrm{KH}_{2} \mathrm{PO}_{4}$ memberikan pengaruh peningkatan pertumbuhan yang tinggi hanya pada 6 jam waktu kultivasi.
\end{abstract}

Kata kunci : bakteri asam laktat, MRS, nutrisi, pH, suhu, pertumbuhan

\section{PENDAHULUAN}

Bakteri asam laktat adalah kelompok bakteri yang telah banyak dipelajari dan dikembangkan sebagai probiotik.Hal ini didasarkan pada (1) bakteri asam laktat merupakan mikroorganisme yang secara genetik adalah aman (memiliki status GRAS). (2) dijumpai melimpah di dalam intestinum, (3) mampu hidup dan melekat di dalam sistem mukosa intestinum, (4) mampu berkompetisi dengan pathogen untuk reseptor pelekatan di epithelium intestinum, (5) mampu berkompetisi terhadap nutrient esensial, (6) menghasilkan asam organik, hidrogen peroksida dan bakteriosin yang bersifat antagonis terhadap pathogen, (7) menghasilkan produk bermanfaat lain seperti enzim ekstraseluler, (8) bersifat noninvasif, nonkarsinogenik dan nonpathogenik, (8) memiliki sejarah panjang digunakan sebagai starter produk makanan dan minuman serta probiotik untuk manusia dan ternak.

Hasil isolasi dan seleksi BAL dari berbagai jenis udang penaeid telah berhasil diperoleh isolat-isolat yang memiliki aktivitas anti vibrio.Bakteri vibrio merupakan 
jenis bakteri utama yang menyerang udang. Pertumbuhan dipengaruhi oleh banyak faktor baik faktor genetik, nutrisi (Todorov \& Diks, 2005b ; Park et al. 2010) maupun lingkungan terutama $\mathrm{pH}$ dan suhu (Messens et al. 2003 ; Zhang et al. 2012).Bakteri asam laktat adalah kelompok bakteri yang bersifat fastidious, membutuhkan medium yang kompleks untuk pertumbuhannya.

Salah satu medium yang biasa digunakan untuk kultivasi bakteri asam laktat adalah medium MRS (Pal et al, 2010). Meskipun MRS merupakan medium kultivasi untuk bakteri asam laktat masih diperlukan untuk dilakukan modifikasi guna mendapatkan formulasi yang optimum sesuai dengan jenis bakterinya. Selaion itu jumlah nutrien yang ada pada medium pertumbuhan awal potensial untuk membentuk biomassa akhir. Sehingga perubahan ketersediaan nutrien ini berpengaruh pada pertumbuhan dan produk biomasa ( Leroy \& de Vuyst, 2001).

Pada penelitian ini dikaji
penambahan komponen nutrisi pada
medium MRS untuk meningkatkan
pertumbuhan dan produksi sel bakteri
asam laktat serta optimasi kondisi
lingkungan kultivasi (pH dan suhu).

\section{MATERI DAN METODE}

\section{Isolat bakteri}

Isolat bakteriyang digunakan dalam penelitian ini adalah adalah isolat BAL yang diisolasi dari udang penaeid dan diseleksi berdasarkan aktivitas anti vibrio terhadap bakteri V.harveyii. V. anguilarum dan V. parahaemolitycus.

\section{Media}

Media yang digunakan untuk produksi BAL adalah medium MRS (Triptone $(10.0 \mathrm{~g} / \mathrm{l})$, ekstrak khamir $(5.0 \mathrm{~g} / \mathrm{l})$, Glukosa (20.0 g/l), $\mathrm{K}_{2} \mathrm{HPO}_{4}(2.0 \mathrm{~g} / \mathrm{l})$, sodium acetate $(5.0 \mathrm{~g} / \mathrm{l}), \mathrm{MgSO}_{4}-7 \mathrm{H}_{2} \mathrm{O}(0.2 \mathrm{~g} / \mathrm{l})$, $\mathrm{MnSO}_{4}-\mathrm{H}_{2} \mathrm{O}(0.05 \mathrm{~g} / \mathrm{l})$, ammonium sulfat $(2.0$ $\mathrm{g} / \mathrm{l})$, Tween $80(1 \mathrm{ml} / \mathrm{l}))$. Komponen nutrisi ditambahkan ke dalam medium MRS meliputi sumber karbon Iglukosa dan fruktosa), sumber nitrogen (ammonium klorida, ammonium nitrat, ammonium sulfat dan pepton) dan sumber $\mathrm{P} \quad\left(\mathrm{K}_{2} \mathrm{HPO}_{4}\right.$ danKH $\mathrm{PHO}_{2}$ ).

\section{Preparasi inokulum}

Satu ose biakan miring diinokulasikan ke dalam $20 \mathrm{~mL}$ medium MRS cair, $\mathrm{pH} 7$ dalam $100 \mathrm{~mL}$ erlenmeyer. Inkubasi pada suhu kamar selama 20 jam. 5 \% inokulum dipindahkan ke dalam $200 \mathrm{~mL}$ médium eksperiment. Inkubasi pada suhu kamar (Sreekumar \& Krishnan, 2010)

\section{Prosedur pengukuran pertumbuhan}

\section{Prosedur pengukuran pertumbuhan dan produksi biomassa}

Pertumbuhan dan produksi biomassa BAL ditentukan berdasarkan kepadatan sel melalui pengukuran OD pada $A_{600}$.

\section{HASIL DAN PEMBAHASAN}

Kepadatan sel bakteri asam laktat pada perlakuan penambahan glukosa dan fruktosa pada pengamatan jam ke 6 menunjukan nilai yang lebih rendah daripada kepadatan di medium MRS tanpa penambahan sumber karbon. Respon peningkatan kepadatan sel cenderung terjadi setelah 12 jam kultivasi. Isolat L-12 memberikan respon peningkatan kepadatan sel yang lebih baik terhadap penambahan glukosa daripada fruktosa. Sebaliknya isolate L-14 memberikan respon peningkatan kepadatan sel yang lebih baik pada penambahan fruktosa daripada glukosa. Hasil penelitian penambahan glukosa dan fruktosa ditunjukan pada Gambar 1

Penambahan ammonium klorida
pada pada awal kultivasi tidak memberikan pengaruh meningkatkan kepadatan sel. Pengaruh meningkatkan kepadatan muncul mulai pengamatan jam ke 18. Sebaliknya penambahan pepton memberikan pengaruh meningkatkan kepadatan sel yang tinggi pada awal kultivasi (pengamatan jam ke 6) tetapi kemudian cenderung menurun besarnya pengaruh mulai pengamatan jam ke 12. Secara grafis ditunjukan pada Gambar 2. 

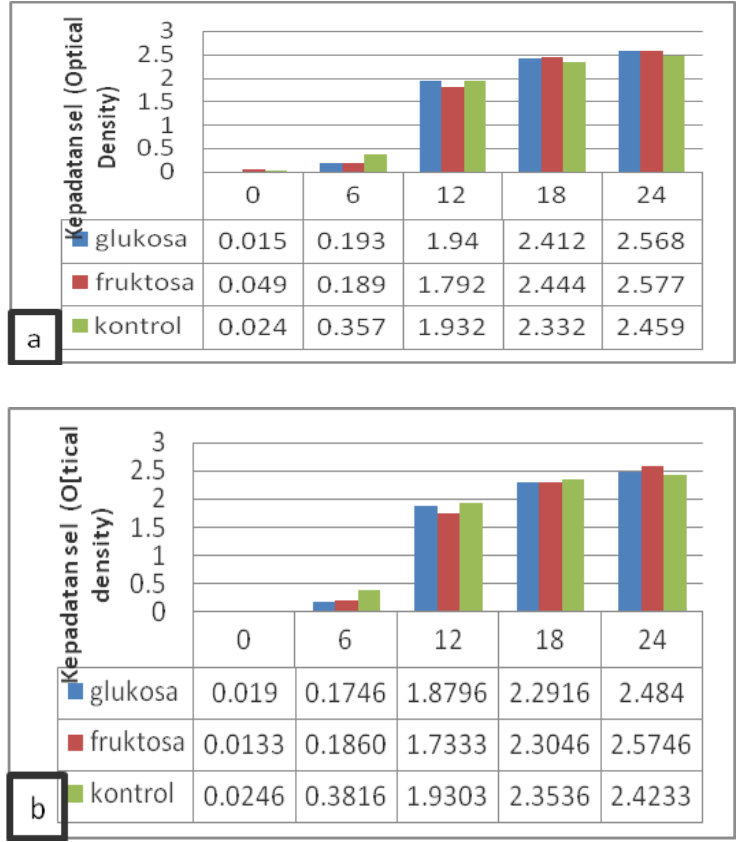

Gambar 1. Kepadatan sel (Optical density) pada kultur bakteri asam laktat : a) isolate $\mathrm{L} 12 ;$ b) isolate L14 dalam media MRS dengan penambahan glukosa dan fruktosa

Penambahan $\mathrm{KH} 2 \mathrm{PO} 4$ dan $\mathrm{K} 2 \mathrm{HPO} 4$ memberikan pengaruh meningkatkan kepadatan sel terjadi hanya pada awal kultivasi yaitu pada pengamatan jam ke 6 . Fenomena ini terjadi pada ke tiga isolate BAL uji.Secara grafis ditunjukan pada Gambar 3.

De Man Rogosa and Sharpe (MRS) merupakan media standard untuk kultivasi bakteri asam laktat (BAL) (Han et al. 2011) dan merupakan media yang paling sesuai untuk media pertumbuhan dan produksi bakteriosin (Arokiyamary \& Sivakumaar, 2011 ; Meng, et al. 2012). Pada medium MRS digunakan glukosa sebagai sumber karbon dengan konsentrasi $20 \mathrm{~g} / \mathrm{L}$. Karbohidrat merupakan sumber $C$ dan energy utama pertumbuhan bakteri asam laktat. Sehingga pertumbuhan dan aktivitas metabosimenya dipengaruhi oleh sumber $\mathrm{C}$ tersedia.Jenis-jenis bakteri asam laktat memiliki perbedaan dalam kebutuhan gulanya.Oleh karena itu meskipun MRS merupakan media standard untuk kultivasi bakteri asam laktat perlu untuk dilakukan modifikasi guna mendapatkan formulasi yang optimum untuk pertumbuhan dan aktivitas metabolism bakteri asam laktat.

Pada penelitian ini penambahan glukosa memberikan efek meningkatan kepadatan sel. Hal ini menunjukan bahwa konsentrasi glukosa yang ada di dalam medium MRS (20 g/L) bukan merupakan konsentrasi yang optimum untuk pertumbuhan ke 3 isolat uji yang digunakan untuk penelitian ini. Hasil penelitian yang serupa dilakukan oleh Hujanen et al (2001) mendapatkan bahwa konsentrasi optimum glukosa untuk produksi asam laktat oleh bakteri L. casei NRRL B41 adalah $160 \mathrm{~g} / \mathrm{L}$. Penelitian yang lain dilakukan oleh Sheeladevi \& Ramanatha (2011) mendapatkan konsentrasi optimum glukosa untuk L plantarum dan L casei sebesar $15 \%$.
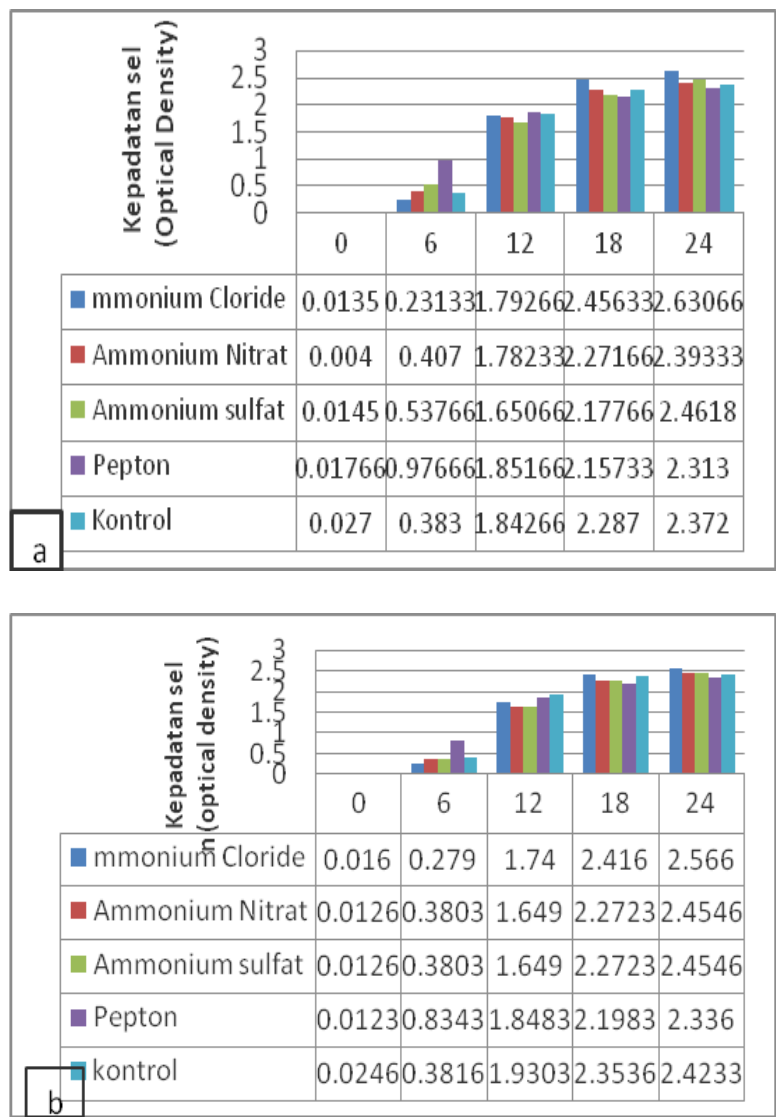

Gambar 2. Kepadatan sel (Optical density) pada kultur bakteri asam laktat : a) isolate $\mathrm{L} 12 ; \mathrm{b})$ isolate $\mathrm{L} 14$ dalam media MRS dengan penambahan berbagai sumber nitrogen 

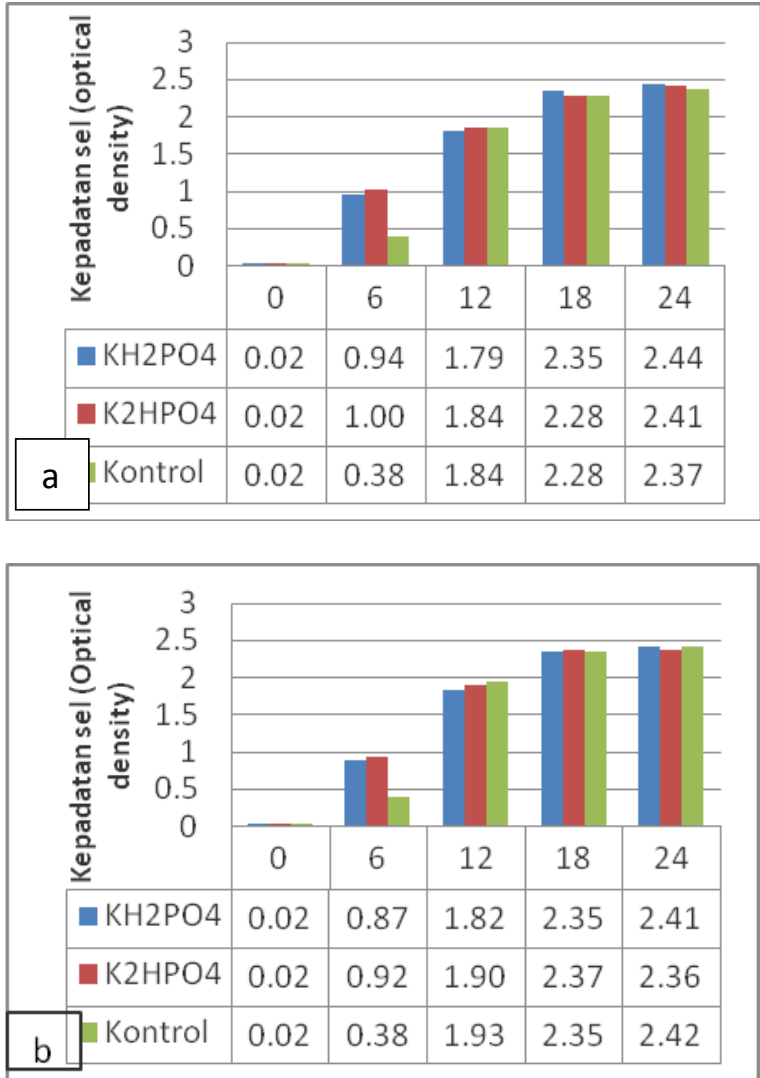

Gambar 3. Kepadatan sel (Optical density) pada kultur bakteri asam laktat : a) isolate $\mathrm{L} 12$; b) isolate L14 dalam media MRS dengan penambahan berbagai sumber phosphat

Menurut hasil penelitian Polak \& Berecka (2010) glukosa merupakan sumber karbon yang paling baik dibandingkan monosakarida dan gula-gula yang lain dengan urutan dari yang terbaik adalah sebagai berikut, glukosa, fruktosa, galaktosa, lactulose, saccharosa dan maltose.

Seperti halnya dengan sumber karbon, pertumbuhan bakteri asam laktat dan aktivitas metabolism dipengaruhi oleh jenis dan konsentrasi sumber nitrogen. Sebagian besar penelitian terkait modifikasi medium MRS terkaait dengan penyediaan sumber $\mathrm{N}$ dilakukan dengan penambahan atau penggantian dengan sumber nitrogen organic seperti pepton, ekstrak khamir dan ekstrak daging serta kombinasi diantaranya. Pada penelitian ini seain menggunakan sumber nitrogen organic yaitu pepton juga dikaji penggunaan penambahan sumber nitrogen anorganik seperti ammonium nitrat, ammonium sulfat dan ammonium klorida. Hasil penelitian menunjukan bahwa penambahan nitrogen anorganik ammonium klorida memberikan efek meningkatkan kepadatan sel. Kejadian ini terjadi pada ke-3 isolat uji.Penelitian penggunaan garam nitrogen untuk kultur bakteri asam laktat juga dilakukan oleh Nancib et al (2001) yaitu menggunakan ammonium sulfat yang dikombinasi dengan ekstrak khamir dengan ratio 4:1. Elena et al (2006) menambahkan garam ammonium ke dalam medium berbasis whey.

Fosfat anorganik secara umum digunakan sebagai buffer demikian juga .di dalam medium MRS K2PO4 berperan sebagai buffer. Pada penelitian ini dilakukan penambahan sumber $\mathrm{P}$ dalam bentuk KH2PO4 dan K2HPO4.Hasil penelitian menunjukan terjadi efek meningkatkan kepadatan sel pada awal waktu kultivasi. Efek yang terjadi pada penambahan garam fosfat ini terjadi melalui mekanisme buffering yaitu pengendalian nilai $\mathrm{pH}$. Menurut Hayek\& Ibrahim (2013) bakteri asam laktat menghasilkan asam terutama asam laktat selama pertumbuhannya, sehingga menyebabkan penurunan $\mathrm{pH}$ dan mengakibatkan kecepatan pertumbuhan menurun. Berdasarkan mekanisme kerja buffer maka dimungkinkan terjadinya efek meningkatkan kepadatan sel pada awal kultivasi oleh penambahan K2HPO4. Produksi asam organic oleh bakteri asam laktat adalah bergantung pertumbuhan atau kepadatan sel. Semakin tinggi kepadatan sel semakin banyak asam yang dihasilkan dan dilepas ke lingkungan, sehingga suatu saat dapat melampaui kapasitas buffering medium dan terjadi penurunan $\mathrm{pH}$ yang nyata, akibatnya pertumbuhan menjadi melambat.

\section{KESIMPULAN}

Medium MRS adalah medium standard untuk kultivasi bakteri asam laktat. Kondisi optimum formulasi medium dan faktor lingkungan untuk pertumbuhan dapat berbeda dan bersifat spesifik pada berbagai jenis bakteri asam laktat. 
Berdasarkan hasil penelitian ini menunjukan bahwa medium MRS dengan komposisinya belum merupakan medium yang optimum untuk pertumbuhan dan produksi sel dari ke 3 isolat bakteri asam laktat yang diuji.

Penambahan komponen nutrisi baik sebagai suber $C, N$ dan $P$ menghasilkan peningkatan pertumbuhan dan kepadatan sel.

Pada kondisi penelitian ini penamabhan glukosa memberikan efek lebih baik dibandingkan fruktosa, penambahan ammonium klorida memberikan efek yang lebih baik dibandingkan sumber nitrogen lain (pepton, amoniumsulfat dan ammonium nitrat), penambahan mineral fosfat baik dalam bentuk KH2PO4 mavoun K2HPO4 menyebabkan peningkatan pertumbuhan dan kepadatan sel.

\section{DAFTAR PUSTAKA}

Todorov S. D., L. M. T. Dicks, 2005, Effect of Growth Medium on Bacteriocin Production by Lactobacillus plantarum ST194BZ, a Strain Isolated from Boza, Food Technol. Biotechnol.43:165-173.

Hayek, S.A., Salam A. Ibrahim, 2013, Current Limitations and Challenges with Lactic Acid Bacteria: A Review, Food and Nutrition Sciences, 4: 73-87

Hujanen .M. S. Linko . Y.-Y. Linko, M. Leisola, 2001, Optimisation of media and cultivation conditions for $\mathrm{L}(+)(\mathrm{S})$-lactic acid production by Lactobacillus casei NRRL B-441 Appl Microbiol Biotechnol : 56:126-130

Meng, Q., Q. Cai, B.Shi, R. Fu, J. Li, X. Chen, K. Qi , M. Zhang, 2012, Optimization of medium composition for production of lacticin LLC518 by Lactococcus lactis subsp. lactis LLC518 using response surface methodology, Journal of Food, Agriculture \& Environment 10 : 137-142.

Messens. W, J. Verluyten, F. Leroy, L. De Vuyst, 2003, Modelling growth and bacteriocin production by Lactobacillus curvatus LTH 1174 in response to temperature and $\mathrm{pH}$ values used for European sausage fermentation processes. Int $J$ Food Microbiol. 81:41-52.
Nancib N, Nancib A, Boudjelal A, Benslimane C, Blanchard F, Boudrant J., 2001, The effect of supplementation by different nitrogen sources on the production of lactic acid from date juice by Lactobacillus casei subsp. rhamnosus. Bioresour Technol. 78:14953.

Elena Mondragón-Parada, M., M. NájeraMartínez, C. Juárez-Ramírez, J. Galíndez-Mayer, N. Ruiz-Ordaz, E. Cristiani-Urbina, 2006, Lactic acid bacteria production from whey, Applied Biochemistry and Biotechnology , 134: 223-232

Pal . A., Ramana K. V. . Bawa A. S., 2010, Simplifi cation and optimization of deMan Rogosa Sharpe(MRS) medium for enhanced production of bacteriocin by Weissella paramesenteroides DFR-8, J Food Sci Technol : 47:258-265.

Leroy, F., L. de Vuyst, 2001, Growth of the Bacteriocin-Producing Lactobacillus sakei Strain CTC 494 in MRS Broth Is Strongly Reduced Due to Nutrient Exhaustion: a Nutrient Depletion Model for the Growth of Lactic Acid Bacteria, Applied and Environmental Microbiology, 67:4407-4413

Park, Y.L., N.K. Lee, K. K. Park, Y. Park, J. M. Kim, H. M. Nam, S. J. Jung, H. D. Paik, 2010, Medium Optimization for Pediocin SA131 Production by Pediococcus pentosaceus SA131 against Bovine Mastitis Using Response Surface Methodology, Korean J. Food Sci. Ani. Resour. 30 : 66 72.

Sheeladevi, A. N.Ramanathan, 2011, Lactic Acid Production Using Lactic Acid Bacteria under Optimized Conditions, International Journal of Pharmaceutical \& Biological Archives 6:1686-1691

Van den Berghe E., G. Skourtas, E. Tsakalidouand L. De Vuyst 2006, Streptococcus macedonicus ACA-DC 198 produces the lantibiotic, macedocin, at temperature and $\mathrm{pH}$ conditions that prevail during cheese manufacture. Int. J. Food Microbiol. $107,138-47$

Wee, Y.J, J.M. Kim, J.S. Yun, H.W. Ryu , 2005, Optimum conditions for the biological production of lactic acid by a newly 
isolated lactic acid bacterium,Lactobacillus sp. RKY2, Biotechnology and Bioprocess Engineering :23-28
Zhang J, Y. Zhang, S.N.Liu, Y. Han , Z.J.Zhou , 2012, Modelling growth and bacteriocin production by Pediococcus acidilactici PA003 as a function of temperature and $\mathrm{pH}$ value, Appl Biochem Biotechnol.166:1388400. 